\title{
Foregut morphology of Macrobrachium carcinus (Crustacea, Decapoda, Palaemonidae)
}

\author{
Jô de Farias LIMA ${ }^{1 *}$, Jamile da Silva GARCIA², Marcos TAVARES ${ }^{3}$ \\ ${ }^{1}$ Brazilian Agricultural Research Corporation - Embrapa Amapá, Rodovia Juscelino Kubitschek, km 5, n²600, CEP: 68906-970, Caixa Postal 10 - Macapá, Amapá, Brazil. \\ 2 University of Amapá, Fishing Engineering Course, Av. Presidente Vargas, nº 650, CEP: 68900-000 Macapá, Amapá, Brazil. \\ ${ }^{3}$ Museum of Zoology, University of São Paulo, Av. Nazaré, 481, Ipiranga, 04263-000 - São Paulo, São Paulo, Brazil. \\ *Corresponding author: jo.lima@embrapa.br
}

\section{ABSTRACT}

Macrobrachium carcinus is a Brazilian native prawn with recognized potential for use in aquaculture activities. The aim of this study was to describe and illustrate in detail the morphology of the $M$. carcinus foregut. The foregut comprises the mouth, esophagus and stomach. It is lined by a simple cylindrical epithelium overlain by chitinous cuticle. The cardiac chamber is well supplied with muscles and lined with chitin thickened in places to form a complex, articulating set of ossicles. The ossicles and setae inside the cardiac chamber seem to direct the food movement through the cardiac chamber and sort the food according to particle size as digestion takes place. Twenty-one basic ossicles were observed in the stomach of $M$. carcinus and are divided into seven categories, reflecting their presumed functional roles. The significance of these morphological features is discussed in terms of its implication in feeding management that can support future commercial farms of this important fishery resource.

KEYWORDS: Freshwater prawn, aquaculture, digestive system, feeding management.

\section{Morfologia do estômago do camarão Macrobrachium carcinus (Crustacea, Decapoda, Palaemonidae)}

\section{RESUMO}

Macrobrachium carcinus é uma espécie nativa com reconhecido potencial para uso em cultivos aquícolas, porém com poucas informaçóes sobre suas estratégias alimentares. O objetivo deste estudo foi descrever e ilustrar em detalhes a morfologia do estômago de $M$. carcinus e fazer uma breve associação com seu hábito alimentar. $\mathrm{O}$ trato digestivo compreende a boca, esôfago e estômago (câmara cardiáca e câmara pilórica) o qual é revestido por um epitélio cilíndrico simples recoberta por uma fina cutícula quitinosa. A câmara cardíaca é bem provida de músculos e margeada por quitina espessada em áreas formando um conjunto complexo de ossículos articulados. Os ossículos e cerdas no interior da câmara cardíaca parecem dirigir a circulação de alimentos através da câmara cardíaca e triar o alimento de acordo com o tamanho de partícula no decorrer da digestão. Umm total de 21 ossículos básicos fazem parte do estômago de $M$. carcinus e estáo divididos em sete categorias de acordo com suas funçôes presumíveis. O significado destas características morfológicas é discutido em termos de sua implicação no manejo alimentar que podem apoiar futuras exploraçóes comerciais deste importante recurso pesqueiro.

PALAVRAS-CHAVE: Pitu, aquicultura, sistema digestivo, estratégia alimentar. 


\section{INTRODUCTION}

The functional morphology of the foregut can provide useful information about the feeding habits of reptant decapod crustaceans (Suthers 1984; Albertoni et al. 2003; Drum 2005). There is much information about the decapod digestive tract, particularly concerning to economically important species, such as palinurids, scyllarids and penaeids (Cox and Bruce 2003; Suthers and Anderson 2006; Abrunhosa and Melo 2008). Little information on the mouthparts or alimentary tract of the genus Macrobrachium Bate 1868 and other caridean prawns has been reported in the literature, as an example larvae of $M$. rosenbergii De Man, 1879 (Abrunhosa and Melo 2002) and M. amazonicum (Heller, 1862) (Queiroz et al. 2011) and adults of M. malcolmsonii (Milne Edwards, 1844) (Patwardhan 1935a), M. acanthurus (Wiegmann, 1836) (Felgenhauer and Abele 1989) and M. carcinus (Lima et al. 2014).

The stomach of carideans prawns exhibits a gradual reduction in the number and development of ossicles and, internal armature that may be more related to the phylogenetic history of the Caridea than to diet (Felgenhauer and Abele, 1989).

In general, macrophagy in crustaceans has been associated with both robust mouthparts and a wellcalcified foregut; reduction of these structures has been established for detritivory (Kunze and Anderson 1979). However, for some natant decapods, this is not a consistent generality (Suthers 1984). Most penaeids such as Penaeus plebejus (Hess, 1865) and P. monodon Fabricius, 1798 are more likely to be predators than scavengers or detrital feeders, since they can capture small fish, small crabs, other penaeids and mollusks (Chong and Sazekumar 1981; Suthers 1984). In general, the ossicles of the gastric mill in the marine shrimps are less calcified than the mouthparts. It follows then that the mastication may occur mostly in the mouthparts (Patwardhan 1935a; Meiss and Norman 1977; Suthers 1984).

The study of the stomach contents of Macrobrachium species has revealed numerous food items as algae, detritus, plant parts, small aquatic insects, juvenile prawns, small fish, and other animals, showing a clear omnivorous diet with an important carnivorous component (Jimoh et al. 2011; Melo and Nakagaki 2013; Lima et al. 2014). The occurrence of animal components indicates that Macrobrachium species and penaeids have similar predation behavior; however, the absence of gastric mill in Macrobrachium (lateral and dorsal teeth) suggests a different mechanism of digestion in the genus (Lima et al. 2014).
The aim of this study was to provide a detailed description and illustration of the foregut morphology in M. carcinus, conduct a comparative study with other palaemonid freshwater prawns, as well as to address the relationships between foregut morphology and feeding behavior. The structural organization of the studied foreguts is compared with other palaemonid prawns and the relationship between the foregut morphology and individual feeding behaviour is discussed.

\section{MATERIALS AND METHODS}

The freshwater prawn used in this study were captured using an artisanal trap called "matapi", baited with flour of babaçu palm fruits (Orbignya speciosa) deployed at depths between 1 and $3 \mathrm{~m}$ in the mouth of the Amazon River: Santana Island (0003'40.9”S and 051'08'46.6”W), Rasa Island (00¹6'08.1"S and 051 $\left.07^{\circ} 25.9^{\prime \prime} \mathrm{W}\right)$, Pequena Island (00¹5'20.0"S and 051'18'10.6”W) and Mazagão Velho (00¹5'39.9'S and 051'20'42.3'W).

The stomachs from 10 adult $(9-15 \mathrm{~cm})$ and 10 juvenile (4-8 $\mathrm{cm}$ ) Macrobrachium carcinus (Linnaeus, 1758), were removed and dissected under a stereomicroscope, and digested in 10\% $\mathrm{KOH}$-solution for $45 \mathrm{~min}$ at $80^{\circ} \mathrm{C}$. All calcified structures of the stomach were stained by adding alizarin red to the heated potassium-solution for 10-15 minutes (Brösing 2002, Lima 2010). After staining, the stomachs were washed in distilled water and stored in 70\% ethanol, then drawn with the aid of a camera lucida (K 400L, Motic, Causeway Bay, Hong Kong). General foregut morphology was described according to the nomenclature proposed by Mocquard (1883), Kunze and Anderson (1979) and Felgenhauer and Abele (1989). Setae was determined using binocular microscope (BA2010, Motic, Causeway Bay, Hong Kong) and nomenclature proposed by Garm (2004).

\section{RESULTS}

The foregut of $M$. carcinus is a thin-walled translucent organ comprised by a mouth, the buccal cavity, esophagus and stomach with two well-differentiated chambers: the cardiac chamber with high volume and a smaller pyloric chamber. The mouth is a transverse slit situated on the ventral side of the head and bounded in front by a massive labrum, behind by a thin bilobed labium, and laterally by the mandibles. The mouth leads into a short buccal cavity that opens posteriorly and dorsally into the short esophagus. The short esophagus (eso) opens into the cardiac chamber whose walls are mostly membranous with numerous longitudinal folds forming the cardiac sac (Csac). This sac expands laterally and toward the posterior portion of the stomach, completely covering the pyloric chamber (Figure 1). 
In ventral view, the stomach of the $M$. carcinus shows the cardiac chamber strengthened by chitinous ossicles joined to each other by ligaments enabling their articulation, especially between the cardiac and pyloric chambers (Figure 2A, B, C). Internally, the cardiac chamber possesses setose lateral ridges (lr) (Figure 3B, C) and lateral valves that may aid in moving the food bolus toward the cardio-pyloric valve, but certainly are not capable of mastication. These folds or channels in the cardiac floor are supported by inferior lateral cardiac ossicles (IX) and show numerous and small simple setae randomly distributed in the internal face (Figure 3B, C). In the upper portion of the channel a dense and orderly row of long serrulate setae (su) forms a comb-like sieve that performs the first filtering process in the stomach (Figure 3B, C). The central portion of the cardiac floor is inclined upwards forming an elongated ventral triangular ridge ( $\mathrm{cfc}$ - cardiac floor crest) bordered by dense row of long simple setae (ss) (Figure 3B, C). At the posterior part of the floor, flaps or valves covering the opening to pyloric stomach (cardio-pyloric valve) support numerous long simple setae.

The cardio-pyloric valve (cpv) is relatively short and regulates, along with the upper portion of the ampullary roof, the passage of the food to pyloric chamber. The sides of the pyloric chamber are pressed inwards to form a small chamber with numerous and elongated simple setae. The floor of this latter chamber is inclined upwards forming the characteristic filtering apparatus, the pyloric filter (PF) (Figures 1, 2 B-C). The filter consists of an outer row of elongated simple setae and an inner row comprising dorsally curved setae where each seta overlaps the next. The dorsal and posterior portion of the pyloric chamber ends in a fold that protrudes toward the anterior region of the stomach, forming a kind of valve that controls the flow of particles into the midgut and down towards the anus, the uropyloric valve (uv) (Figure $4 \mathrm{~B})$. The opening between the foregut and the midgut is tight by a pair of folds filled internally with tufts of elongated simple setae (Figure 4B).

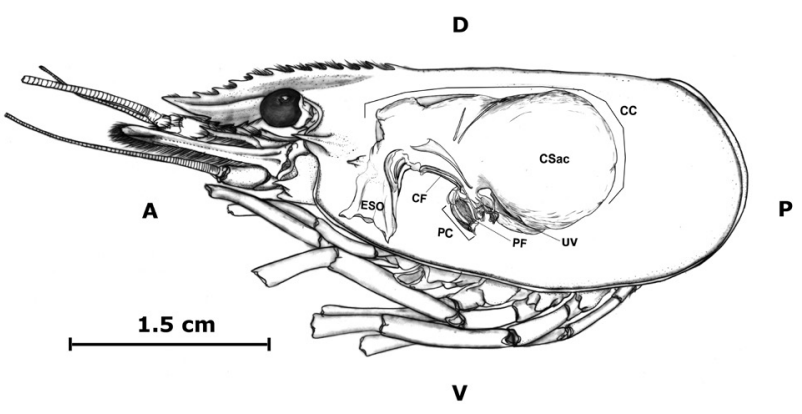

Figure 1. Lateral view showing schematic position of stomach in Macrobrachium carcinus. Abbreviation: A - anterior portion, D - dorsal portion, $\mathrm{P}$ - posterior portion, $\mathrm{V}$ - ventral portion, CSac - cardiac sac, ESO - esophagus, CF - cardiac floor, CC - cardiac chamber, PC - pyloric chamber, PF - pyloric filter, UV - uropyloric valve.
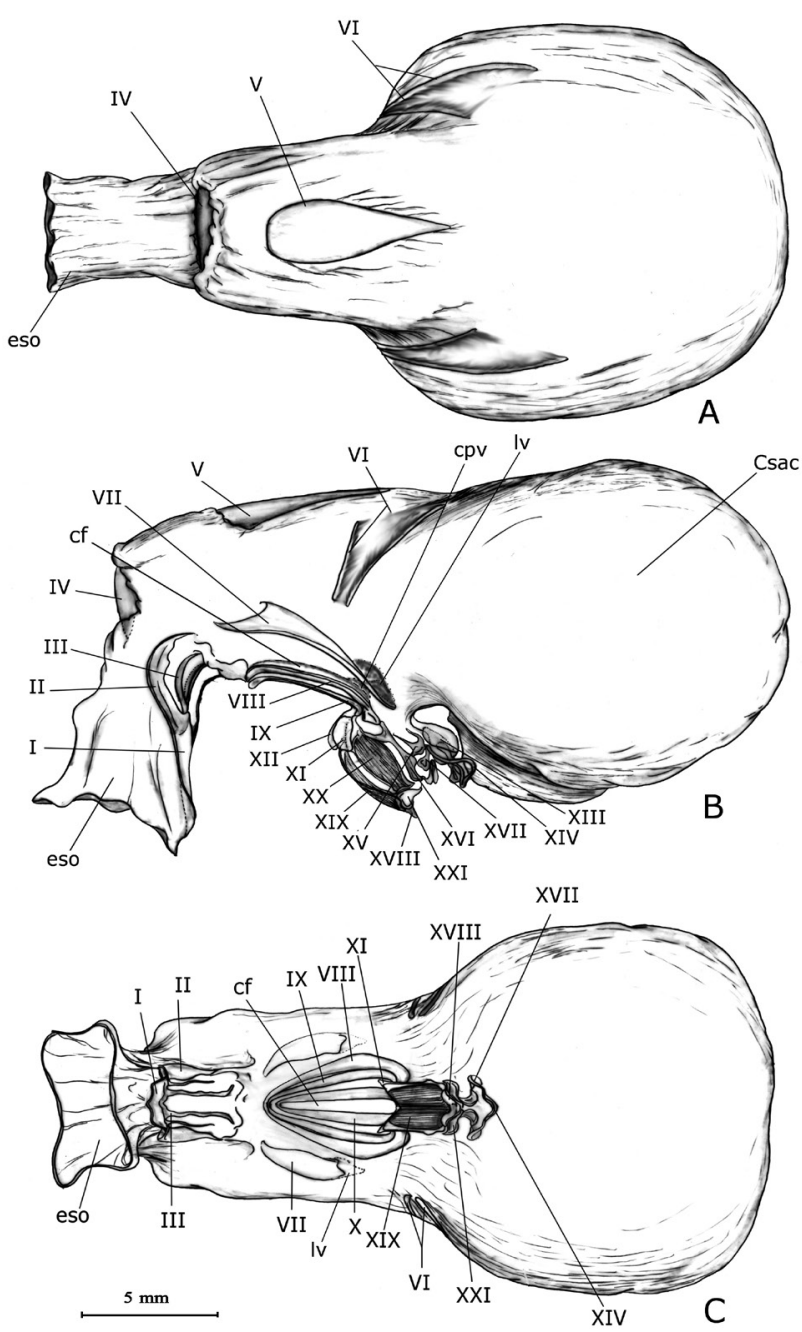

Figure 2. Stomach of Macrobrachium carcinus in dorsal (A), lateral (B) and ventral $(C)$ views. Abbreviation: cf - cardiac floor, $\mathrm{cpv}$ - cardio-pyloric valve, csac - cardiac sac, eso- esophagus, Iv - lateral valve. Meaning of Roman numeral as indicated in Table 1.

A total of 21 basic ossicles (Table 1) were observed in the stomach of $M$. carcinus, being divided into seven categories, reflecting their presumed functional roles: 1 - esophageal ossicles; 2 - supporting ossicles of the cardiac stomach; 3 - ossicles of the cardio-pyloric valve; 4 - supporting ossicles of the dorsal pylorus; 5 - supporting ossicles of the lateral pylorus; 6 - supporting ossicles of the ventral pylorus and ampullae; 7 - supra-ampullary supporting ossicles.

\section{Esophageal ossicles}

This group shows three longitudinal calcified plates: anterior esophageal plate (I), lateral esophageal plate (II) and middle esophageal plate (III) (Figure 2B-C). The unpaired anterior esophageal plate (I) is subtriangular and lightly calcified. It articulates to the anterior margin of the 


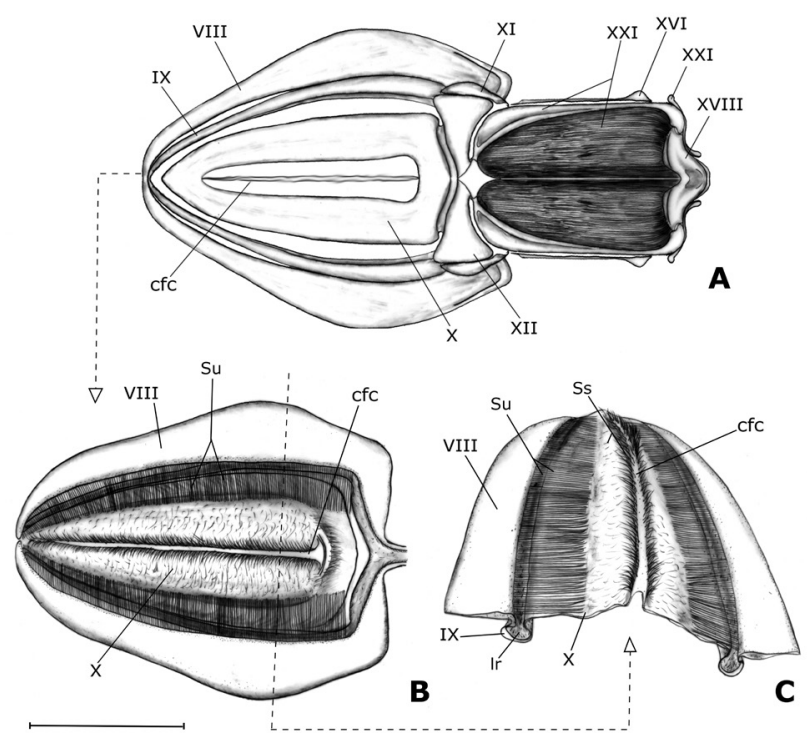

Figure 3. Detail of stomachal skeleton of Macrobrachium carcinus. A cardiac ossicles in ventral view; B - cardiac floor in dorsal view showing setal arrangement and $\mathrm{C}$ - section transversal of cardiac flor with detail of setose lateral ridges and ventral triangular ridge. Abbreviation: cfc - cardiac floor crest, Ir - lateral ridges, ss - simple setae, su - serrulate setae. Scales: $2 \mathrm{~mm}$. Meaning of Roman numeral as indicated in Table 1. lateral esophageal plate (II) and the middle esophageal plate (III) via a thin chitinous membrane. The paired lateral esophageal plate (II) is sickle-shaped and lightly calcified. It is situated in the ventrolateral portion and covers little more than half of the esophagus. The unpaired middle esophageal plate (III) has "U" form and lightly calcification. It is located mesially in the posterior portion of esophagus (Figure 2B-C).

\section{Supporting ossicles of the cardiac stomach}

This group is formed by six calcified ossicles, probably with supporting function: cardiac disc (IV), mesourocardiac plates $(\mathrm{V})$, dorsolateral cardiac filament $(\mathrm{VI})$, lateral cardiac plate (VII), posterior cardiac plate (VIII) and inferior lateral cardiac ossicle (IX) (Figure 2A-C). The unpaired cardiac disc (IV) is located immediately in front of the cardiac chamber and has a discoid form. The unpaired meso-urocardiac plate $(\mathrm{V})$ is located mesially in the dorsal face of cardiac chamber and has a drop-like shape (Figure 2A-B). The paired dorsolateral cardiac plates (VI) are two long, slightly calcified pieces located in the lateral margins of cardiac chamber (Figure 2B-C). The paired lateral cardiac plate (VII) consists of a prominent

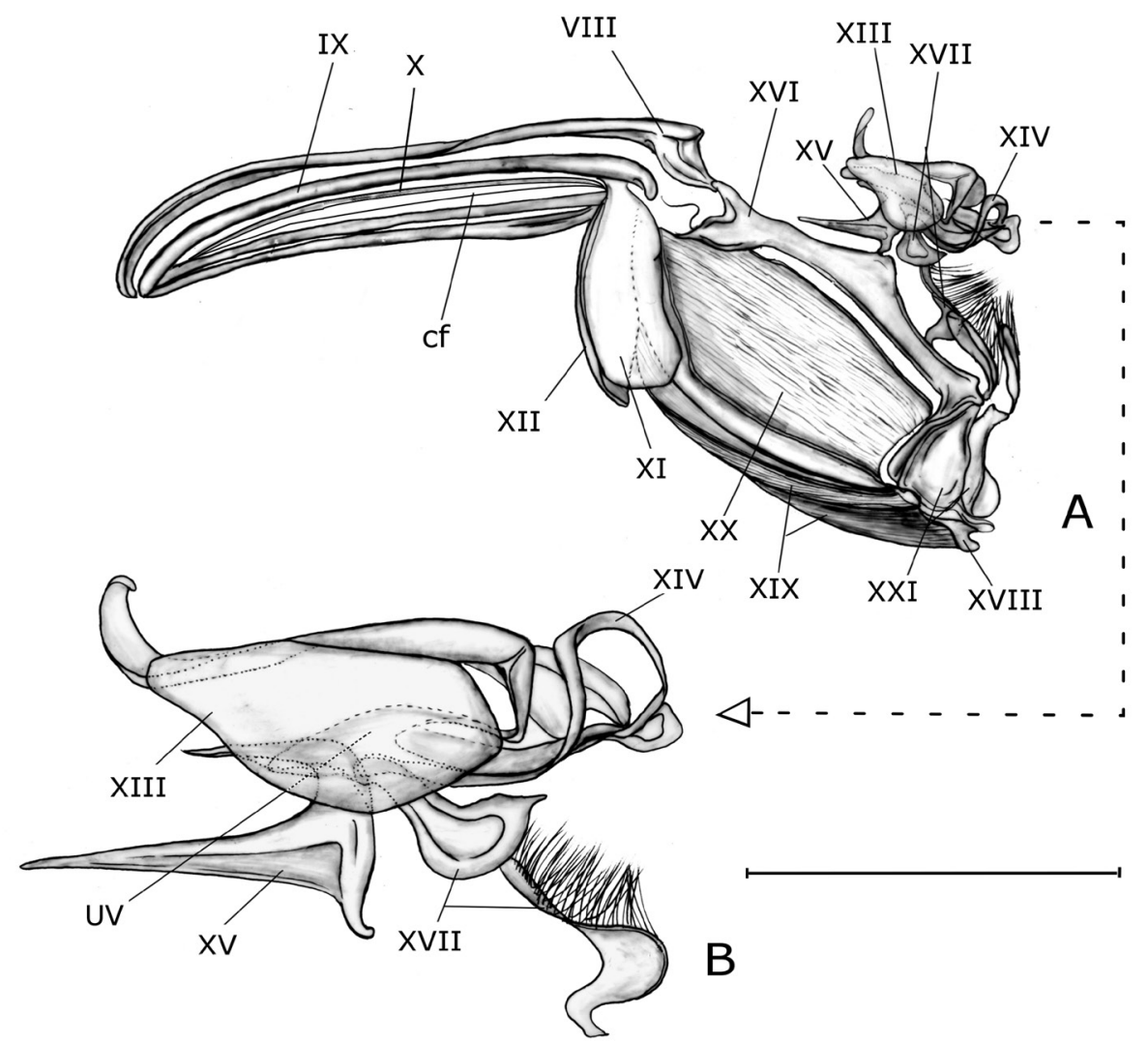

Figure 4. Detail of stomachal skeleton of Macrobrachium carcinus. A - pyloric ossicles in lateral view; B - detail of dorsal ossicles and uropyloric valve of pyloric chamber. Abbreviation: cf - cardiac floor, uv - uropyloric valve. Scales: A $=0.42 \mathrm{~mm}, \mathrm{~B}=0.15 \mathrm{~mm}$. Meaning of Roman numeral as indicated in Table 1 . 
Table 1 - Foregut ossicles of the Macrobrachium carcinus. Roman numerals used in figures are also provided.

\begin{tabular}{|c|c|c|}
\hline Group of ossicles & Status & Roman numeral \\
\hline \multicolumn{3}{|l|}{ Esophageal ossicles } \\
\hline anterior esophageal plate & unpaired & I \\
\hline lateral esophageal plate & paired & ॥ \\
\hline middle esophageal plate & unpaired & III \\
\hline \multicolumn{3}{|l|}{ Supporting ossicles of the cardiac stomach } \\
\hline cardiac disc & unpaired & IV \\
\hline meso-urocardiac plate & unpaired & V \\
\hline dorsolateral cardiac plate & paired & VI \\
\hline lateral cardiac plate & paired & VII \\
\hline posterior cardiac plate & paired & VIII \\
\hline inferior lateral cardiac ossicle & paired & IX \\
\hline \multicolumn{3}{|l|}{ Ossicles of the cardio-pyloric valve } \\
\hline anterior ossicle of the cardio-pyloric valve & unpaired & $x$ \\
\hline lateral ossicle of the cardio-pyloric valve & paired & $X I$ \\
\hline posterior ossicle of the cardio-pyloric valve & paired & XII \\
\hline \multicolumn{3}{|l|}{ Supporting ossicles of the dorsal pylorus } \\
\hline uropyloric ossicle & unpaired & XIII \\
\hline posterior uropyloric ossicle & unpaired & XIV \\
\hline \multicolumn{3}{|l|}{ Supporting ossicles of the lateral pylorus } \\
\hline anterior pleuropyloric ossicle & paired & $X V$ \\
\hline middle pleuropyloric ossicle & paired & $\mathrm{XVI}$ \\
\hline posterior pleuropyloric ossicle & paired & XVII \\
\hline \multicolumn{3}{|c|}{ Supporting ossicles of the ventral pylorus and ampullae } \\
\hline posterior inferior pyloric ossicle & unpaired & XVIII \\
\hline inferior ampullary ossicle & paired & $\mathrm{XIX}$ \\
\hline superior ampullary ossicle & paired & $X X$ \\
\hline \multicolumn{3}{|l|}{ Supra-ampullary supporting ossicle } \\
\hline posterior supra-ampullary ossicle & paired & XXI \\
\hline
\end{tabular}

longitudinal fold located between the junction of the cardiac floor (cf) and the sides of the cardiac chamber, forming the lateral valve (lv) (Figure 2B-C). The paired posterior cardiac plate (VIII) and paired inferior lateral cardiac ossicle (IX) sustain the ventral portion of the cardiac chamber. These pieces are elongated and form a shallow trough that carries food into the pyloric chamber, which is guarded by the cardio-pyloric valve (cpv) (Figure 2B).

\section{Ossicles of the cardio-pyloric valve}

This group consists of three calcified ossicles: the anterior ossicle of the cardio-pyloric valve $(\mathrm{X})$, the lateral ossicle of the cardio-pyloric valve (XI) and the posterior ossicle of the cardio-pyloric valve (XII) (Figure 2B-C, 3A-C, 4A). The unpaired anterior ossicle of the cardio-pyloric valve $(\mathrm{X})$ consists of a thin calcified triangular plate located between the posterior margins of the paired inferior lateral cardiac ossicles (IX) and extends into the depths of the cardiopyloric valve (cpv). The unpaired posterior ossicle of the cardio-pyloric valve (XII) guards the posterior margin of the cardio-pyloric valve and is clearly separated by a membrane from the paired lateral ossicle of the cardio-pyloric valve (XI) (Figure 2B-C, 3A, 4A).

\section{Supporting ossicles of the dorsal pylorus}

In the dorsal portion of the pyloric chamber, two weakly calcified ossicles are observed. The unpaired uropyloric ossicle (XIII) is moderately calcified with the anteromesial portion projected in a wide ribbon that folds over, back and forth, forming the dorsal median valve, while the posterior mesial portion shows an elongated and filamentous projection, that curves down 
and forward in where it connects with the unpaired posterior uropyloric ossicle (XIV), forming the uropyloric valve (uv) (Figures 2B-C, 4A-B). The unpaired posterior uropyloric ossicle (XIV) is moderately calcified, with lateral edges showing as an elongated strip-shaped projection, connected side by side with the paired posterior pleuropyloric ossicle (XVII) (Figures 2B-C, 4A-B).

\section{Supporting ossicles of the lateral pylorus}

This group consists of three calcified ossicles: the anterior pleuropyloric ossicle (XV), the middle pleuropyloric ossicle (XVI) and the posterior pleuropyloric ossicle (XVII) (Figures 2B-C, 4A$\mathrm{B})$. The anterior pleuropyloric ossicles (XV) consist of a pair of strongly calcified pieces with the anterior portion showing as an elongated and tapering process, while the posterior portion forms a type of strap. The paired middle pleuropyloric ossicle (XVI) is strongly calcified and forms an elongated bar located back over its ampullary roof. In In M. carcinus the pleuropyloric ossicle connects to the posterior cardiac plate (VIII) by its anterior portion, to the posterior supra-ampullary ossicle (XXI) by the posterior portion and to the anterior pleuropyloric ossicle (XV) by the dorsal portion (Figures 2B-C, 4A-B).

\section{Supporting ossicles of the ventral pylorus and ampullae}

This group consists of three calcified ossicles. The unpaired posterior inferior pyloric ossicle (XVIII) is a "v" shape" structure strongly calcified (Figures 2B-C, 4A-B). It is located in the posterior ventral pyloric chamber and articulates with the inferior ampullary ossicle (XIX) by the posterior and dorsal margins and with the anterior pleuropyloric ossicle (XV) by the dorsal margin (Figures 2B-C, 4A-B). The paired superior ampullary ossicle (XX) is a hemispherical plate with numerous longitudinal grooves (Figures 2B-C, 4A-B). In this ossicle the anterior margin is slightly narrow and rounded the posterior margin is wide and truncated. It is located in the posterior ventrolateral portion of the pyloric chamber (Figures 2B-C, 4A-B).

\section{Supra-ampullary supporting ossicle}

This functional group consists of a single ossicle, the posterior supra-ampullary ossicle (XXI). This piece is a subtriangular plate with a strong ridge protruding from the dorsal margin. It is located in the posterior ventrolateral portion of the pyloric chamber, between the posterior inferior pyloric ossicles (XVIII) and the middle pleuropyloric ossicle (XVI) (Figures 2B-C, 4A-B).

\section{DISCUSSION}

Although the stomach of $M$. carcinus conforms the general decapod body plan, with esophagus, cardiac and pyloric chambers, cardio-pyloric valve and articulated ossicles, its morphology has certain particular characteristics that differ from penaeids, lobsters and crabs. The opening between the cardiac stomach and esophagus in $M$. carcinus is not guarded by especial valves as reported for other crustaceans (Brösing 2010; Alves et al. 2010), but by esophageal plates. As already reported for $M$. malcolmsoni, $M$. acanthurus, $M$. rosenbergii and Palaemonetes argentinus Nobili 1901 (Felgenhauer and Abele 1989; Thonggamgaew 2004; Sousa and Patriella 2006).

Contrary to Sousa and Petriella (2006) who suggested that in Palaemonetes argentinus the ingested food could be easily regurgitated due to the absence of an esophageal valve, the position and organization of the esophageal plates in M. carcinus is indicative of control of entry and exit of food and other particles into the stomach.The esophageal probably serve to guide the food backwards besides its possible role a supporting structure. The lateral valves in $M$. carcinus are morphologically similar to the ones found in $M$. malcolmsonii, $M$. acanthurus and $M$. rosenbergii (Patwardhan 1935b; Felgenhauer and Abele 1989; Thonggamgaew 2004). According to Patwardhan (1935b), the lateral valves correspond in position to the lateral teeth of brachyuran and anomuran crabs, and are thus structures homologous.

In M. carcinus the morphology and setal arrangement of the cardiac floor are similar to the ones reported by Thonggamgaew (2004) for $M$. rosenbergii. The cardiac floor is mainly occupied by median triangular ridge, is was covered with small setae, and possessed the comb-like filtering organs (sieves) lining along the median triangular ridge. At the posterior part of the cardiac floor, there flaps or valves covering the opening to pyloric stomach.

Except for striking variations in the length of the lateral cardiac plates (VII), the posterior cardiac plates (VIII) and the inferior lateral cardiac ossicles (IX) in M. carcinus, the skeletal structure of the cardiac chamber is remarkably uniform as already noticed by other authors (Mocquard 1883; Patwardhan 1935b).

Except for striking variations in the length of the lateral cardiac plates (VII), the posterior cardiac plates (VIII) and the inferior lateral cardiac ossicles (IX) in M. carcinus, the skeletal structure of the cardiac chamber is remarkably uniform as already noticed by other authors (Mocquard 1883; Patwardhan 1935b). The cardiac chamber of $M$. carcinus is the largest part of the stomach, as similarly observed in M. malcolmsonii (Patwardhan 1935b), M. acanthurus (Felgenhauer and Abele 1989), and P. argentinus (Sousa and Patriella 2006). Its narrow anterior part is continuous with the esophagus while the rest of the stomach is pear-shaped. The cardiac sac in $M$. carcinus expands is pear-shaped, covering the pyloric chamber, while in crabs, lobsters and penaeid shrimps is expanded toward the anterior portion of the cardiac 
chamber (Hobbs and Hooper 2009; Brösing 2010; Jha and Homechaudhuri 2001). As in other palaemonid prawns (Mocquard 1883; Patwardhan 1935b; Sousa and Patriella 2006), the gastric mill in M. carcinus is substantially different from that of penaeids, lobsters and brachyuran crabs.

The pyloric chamber in $M$. carcinus shares similar general characteristics with other palaemonid prawns (Patwardhan 1935b; Felgenhauer and Abele 1989; Sousa and Patriella 2006). Its double filter retains large particles while allowing small particles to pass through it; the filter setae pressthe finest particles towards the inner filter and eliminate the big particles towards the midgut, increasing the filter efficiency (Kunze and Anderson 1979; Lin 2000).

The cardiac and pyloric chambers are sustained by chitinous ossicles joined to each other by ligaments enabling their articulation; however, it is numerically and morphologically varied in Decapoda (Hobbs and Hooper 2009; Alves et al. 2010; Reimann et al. 2011). The number of ossicles observed in the cardiac stomach of $M$. carcinus is higher comparativelly to other caridean prawns (Mocquard 1883; Patwardhan 1935b). The cardiac disc (IV) in M. carcinus is similar to that reported for in other Macrobrachium species and is also similar to the disc of pagurids and lithodids (Mocquard 1883; Patwardhan 1935b; Reimann et al. 2011). The cardiac disc is absent however in penaeid shrimps. In M. carcinus the cardiac disc piece helps to sustain the cardiac sac. The meso-urocardiac plate (V) clearly observed in $M$. carcinus has not been reported in M. malcolmsoni and in $M$. acanthurus, probably due to its soft calcification (Patwardhan 1935b; Felgenhauer and Abele 1989).

The posterior cardiac plate (VIII),inferior lateral cardiac ossicles (IX) and anterior ossicle of the cardiopyloric valve (X) are fairly thick and each of them is provided with a single linear row of stout setae projecting horizontally over a ventral groove between the external and the internal ridges of its side, which helps directing food for cardio-pyloric valve as reported by Patwardhan(1935b) and Mocquard (1883). In $M$. carcinus the supporting ossicles of the dorsal pylorus have similar morphology to that reported for $M$. malcolmsonii by Patwardhan (1935b), and probably same function.

The supporting ossicles of the lateral pylorus are also found in some penaeid shrimps, also found in some penaeid shrimps (Meiss and Norman 1977; Suthers 1984), but not the anterior pleuropyloric ossicle (XV). In Farfantepenaeus duorarum (Burkenroad, 1939), F. aztecus (Ives, 1891) and Penaeus plebejus Hess, 1865, but absent in $M$. carcinus. The Supporting ossicles of the ventral pylorus and ampullae of $M$. carcinus are also found in other caridean shrimps (Mocquad 1883; Patwardhan 1935b), penaeids (Patwardhan 1935c; Suthers 1984; King and Alexander 1994) and crabs (Brösing 2010), and have similar morphology. On the other hand, the posterior supra-ampullary ossicle (XXI) is the only supporting ossicle found in $M$. carcinus it is similar in position to the corresponding ossicle of the penaeid shrimps (Suthers 1984; King and Alexander 1994). The supra-ampullary ossicle (XXI) is herein reported for the first time in palaemonid prawns.

\section{General mechanism of digestion}

The general features of $M$. carcinus digestive tract are not similar to those of most other decapods. The presence and action of the gastric mill, typically reported in many decapods (e.g. Kunze and Anderson 1979; Hobbs and Hooper 2009; Brösing 2010), were not observed in this study. The general morphology of the foregut of $M$. carcinus and other palaemonid prawns indicates that the food trituration and digestion occurs normally at the level of the stomach and not only by the mechanical action of the mandibles as suggested by Meiss and Norman (1977). However, the grinding surfaces of the lateral teeth, typical of penaeid shrimps, is absent in $M$. carcinus and the food trituration is feasible only because of the large amount of sand in the diet, along with gastric juices and the motion of the cardiac chamber (Lima et al. 2014).

The presence of sand and other sediments in the stomach of decapod crustaceans has been reported by many authors, especially by accidental ingestion with preys (Branco and Moritz-Jr 2001; Branco and Lunardon-Branco 2002; Jimoh et al. 2011). Because $M$. carcinus does not has a true gastric mill, other calcified pieces, with possibly sustentation function, such as lateral cardiac plate (VII), posterior cardiac plate (VIII) and inferior lateral cardiac ossicle (IX), can help the maceration process. These pieces are elongated and form a shallow trough that often supports sand grains and little pebbles that through the constant peristaltic movements of the stomach are mixed with food, helping the digestion. As observed by Lima et al. (2014), food maceration in M. carcinus is facilitated by the large amount of sand in the diet which, along with the motion of the cardiac stomach, functions similarly to a gastric mill; such a mechanism is capable of breaking down large fleshy pieces (see also Coombs and Allen 1978; Suthers 1984 and references therein). We thus suggest that culturing M. carcinus in eathern ponds would possibly enhance digestion efficiency. 


\section{CONCLUSIONS}

Foregut morphology of adult and juvenile specimens of $M$. carcinus is similar. The stomach of $M$. carcinus revealed ossicles with supporting functions mainly. The esophageal plates possibly control food and passage of particles through the gut, operating, therefore, as a valve. The cardiac stomach has supporting ossicles that presumably serve to guide the food and mix with stomach acids. The gastric mill proper is absent in $M$. carcinus but this does not limit simultaneous digestion of plant and animal food items. The stomach's general morphology indicates that the sand ingestion by $M$. carcinus probably occurs to help in the food maceration in response to the absence of gastric mill or teeth in the stomach. The foregut morphology in $M$. carcinus suggests that this species will have its best development if farmed in earthen ponds.

\section{ACKNOWLEDGMENT}

The study was supported financially by Brazilian Corporation of Agricultural Research (Embrapa) by the project MP3 1/2008 - No 03081470000, whose research data provided the basis for the development of this work. We greatly thank to Chico Mendes Institute for Biodiversity Conservation (ICMBio) for the collect authorization (SISBIO no 17702).

\section{REFERENCES}

Abrunhosa, F.A.; Melo, M.A. 2002. Morfologia comparativa do estômago do primeiro e último estágios zoea e juvenil i de Macrobrachium rosenbergii (De Man, 1879) (Decapoda: Palaemonidae). Revista Ciência Agronômica, 33: 5-12.

Abrunhosa, F.A.; Melo, M.A. 2008. Development and functional morphology of the foreguts of larvae and postlarvae of three crustacean decapods. Brazilian Journal of Biology, 68: 221-228.

Albertoni, E.F.; Palma-Silva, C.; Esteves, F.A. 2003. Natural diet of three species of shrimp in a tropical coastal lagoon. Brazilian Archives of Biology and Technology, 46:395-403.

Alves, S.T.M.; Abrunhosa, F.A.; Lima, J.F. 2010. Foregut morphology of Pseudothelphusidae and Trichodactylidae (Crustacea: Decapoda) from northeastern Pará, Brazil. Zoologia, 27:228-244.

Branco, J.O.; Lunardon-Branco, M.J. 2002. Ecologia trófica de Portunus spinimanus Latreilli 1819, na armação do Itapocoroy, Penha, Santa Catarina. Revista Brasileira de Zoologia, 19: 723729.

Branco, J.O.; Moritz-Jr, H.C. 2001. Alimentaçáo natural do camarão sete-barbas, Xiphopenaeus kroyeri (Heller) (Crustacea, Decapoda), na Armação do Itapocoroy, Penha, Santa Catarina. Revista Brasileira de Zoologia, 18: 53-61.

Brösing A. 2002. Die Magenstrukturen der Brachyura (Crustacea, Decapoda), Morphologie und phylogenetische Bedeutung. Unpublished Ph.D. dissertation, Humboldt Universität zu Berlin, 260 p.
Brösing, A. 2010. Recent developments on the morphology ofthe brachyuran foregut ossicles and gastric teeth. Zootaxa, 2510: $1-44$.

Chong, V.C.; Sazekumar, A. 1981. Food and feeding habitats of the white prawn Penaeus merguiensis. Marine Ecology Progress Series, 5: 185-191.

Coombs, E.F.; Allen, J.A. 1978. The functional morphology of feeding appendages and gut of Hippolyte varians (Crustacea, Natantia). Zoological Journal of the Linnean Society, 64: 261-282.

Cox, S.L.; Bruce, M.P. 2003. Feeding behaviour and associated sensory mechanisms of stage I-III phyllosoma of Jasus edwardsii and Jasus verreauxi. Journal of the Marine Biological Association of the UK, 83: 465-468.

Drum, D.T. 2005. Comparative morphology of the mouthparts, chelipeds and foregut of two kalliapseudid apseudomorphans (Crustacea: Tanaidacea). Proceedings of the Academy of Natural Sciences of Philadelphia, 154: 137-147.

Felgenhauer, B.E.; Abele, L.G. 1989. Evolution of the foregut in lower Decapoda. In: Felgenhauer, B. E.; Watling, L. and Thistle, A. B. (Eds.). Functional morphology of feeding and grooming in Crustacea. Crustacean Issues, 6: 205-219.

Garm, A. 2004. Revising the definition of the crustacean seta and setal classification systems based on examinations of the mouthpart setae of seven species of decapods. Zoological Journal of the Linnean Society, 142:233-252.

Hobbs, K.H.; Hooper, S.L. 2009. High-Resolution computed tomography of lobster (Panulirus interruptus) stomach. Journal of Morphology, 270: 1029-1041.

Jha, A.; Homechaudhuri, S. 2001. Understanding the gastric mill structure of a macrophagous shrimp Metapenaeus monoceros (Fabricius). Current Science, 80: 620-622.

Jimoh, A.A.; Clarke, E.O.; Whenu, O.O.; Adeoye, H.B. 2011. Food and feeding habits of the african river prawn (Macrobrachium vollenhovenii, Herklots, 1857) in Epe Lagoon, southwest Nigeria. International Journal of Fisheries and Aquaculture, 3: 10-15.

King, R.A.; Alexander, C.G. 1994. Fluid extraction and circulation in the proventriculus of the banana prawn Penaeus merguiensis De Man. Journal of Crustacean Biology, 14: 497-507.

Kunze, J.; Anderson, D.T. 1979. Functional morphology of the mouthparts and gastric mill in the hermit crabs Clibanarius taeniatus (Milne-Edwards), Clibanarius virescens (Krauss), Paguristes squamosus McCulloch and Dardanus setifer (MilneEdwards) (Anomura-Paguridae). Australian Journal of Marine and Freshwater Research, 30: 683-722.

Lima, J.F. 2010. Esqueleto gástrico nos Gecarcinidae Macleay, 1838 (Crustacea: Decapoda: Brachyura): Implicações filogenéticas. Tese Doutorado, Universidade Federal do Pará/Museu Paraense Emílio Goeld, Belém-PA, Brasil, 145p.

Lima, J.F.; Da Silva J.G.; Da Silva, T.C. 2014. Natural diet and feeding habits of a freshwater prawn (Macrobrachium carcinus: Crustacea, Decapoda) in the estuary of the Amazon River. Acta Amazonica, 44: 235-244.

Lin, F.Y. 2000. Scanning electron microscopic observations on the gland filters of the pyloric stomach of Penaeus monodon and 
Metapenaeus ensis (Decapoda, Penaeidae). Crustaceana, 73: 163-174.

Meiss, D.E.; Norman, R.S. 1977. Comparative study of the stomatogastric system of several decapod crustacea: I Skeleton. Australian Journal of Marine and Freshwater Research, 152:21-54.

Melo, M.S.; Nakagaki,M. 2013. Evaluation of the feeding habits of Macrobrachium brasiliense (Heller, 1862) in the Curral de Arame stream (Dourados/Mato Grosso Do Sul, Brazil). Nauplius 21: 25-33.

Mocquard, M.F. 1883. Recherches anatomiques sur l'estomac des Crustacés podophthalmaires. Annales des Sciences Naturelles, 16: $1-311$.

Patwardhan, S.S. 1935a. On the structure and mechanism of the gastric mill in Decapoda. V. The structure of the gastric mill in natantous Macrura-Caridea. Proceedings of the Indian Academy of Science B, 1: $693-704$.

Patwardhan, S.S. 1935b On the structure and mechanism of the gastric mill in Decapoda. IV. The structure of the gastric mill in reptantous Macrura. Proceedings of the Indian Academy of Science $B, 1: 414-422$.

Patwardhan, S.S. 1935 c. On the structure and mechanism of the gastric mill in Decapoda. VI. The structure of the gastric mill in natantous Macrura-Peneidea and Stenopidea: conclusion. Proceedings of the Indian Academy of Science B, 2: 155 - 174.

Queiroz, L.D.; Abrunhosa, F.A.; Maciel, C.R. 2011. Ontogenesis and functional morphology of the digestive system of the freshwater prawn, Macrobrachium amazonicum (Decapoda: Palaemonidae). Zoology, 28: 395-402.
Reimann A.; Richter S.; Scholtz G. 2011. Phylogeny of the Anomala (Crustacea, Decapoda, Reptantia) based on the ossicles of the foregut. Zoologischer Anzeiger 250: 316-342.

Sousa, L.; Patriella, A.M. 2006. Morphology and histology of $P$. argentinus (Crustacea, Decapoda, Caridea) digestive tract. Biocell, 30: $287-294$.

Suthers, I.M. 1984. Functional morphology of the mouthparts and gastric mill in Penaeus plebejus Hess (Decapoda: Penaeidea). Australian Journal of Marine and Freshwater Research, 35: 785792.

Suthers, I.M.; Anderson, D.T. 2006. Functional morphology of mouthparts and gastric mill of Ibacus peronii (Leach) (Palinura : Scyllaridae). Australian Journal of Marine and Freshwater Research, 32: 931-944.

Thonggamgaew, S. 2004. The morphological study of gastrointestinal tract of Macrobrachium rosembergii (De Man, 1879) (Decapoda: Palemonidae). Dissertation, Master of Science (Veterinary Anatomy) Graduate School, Kasetsart University, Bang Khen, Bangkok, Thailand, 140p.

Recebido em 05/04/2015

Aceito em 06/08/2015 
